\title{
The effects of COVID 19 on implementing the secondary school curriculum: The case of Morogoro municipality
}

\author{
${ }^{1}$ Damas Mkeli Mbosa \& ${ }^{2}$ Noah Mtana \\ 1. Student at Jordan University College, P.O. Box 1878 Morogoro, Tanzania. \\ 2. Department of Education, Jordan University College, P.O. Box 1878 Morogoro, Tanzania. \\ Tel: 255-786337063. E-mail: macd17.dm@gmail.com
}

\begin{abstract}
The aim of this study was to look on the effects of the COVID 19 on the implementation of secondary schools curriculum in Morogoro Municipality. The objectives of this study were to assess curriculum implementation before the COVID 19, to find out what happened to the curriculum implementation when schools were closed and to determine compensatory strategies after schools were opened. The study involved 5 (five) Ordinary secondary schools with different socio-economic status. There were 90 respondents; these include 60 Form three students, 10 Parents, and 20 Teachers. It mainly employed qualitative approach. Data were collected through semi- structured interviews and focus group discussion. Data analysis was done qualitatively. The study was mainly guided by Socio-cultural (Social Constructivism) theory. The theory was thought to be an appropriate theoretical framework to underpin this study. This theory helps to explain how curriculum implementation was influenced by the level of learner's assistance to learn. The study used case study research design. Findings show that before the pandemic students were all well supported to learn both at home and at school where teachers, peer students and parents played the role of supporting the learners. Findings show that when schools were closed there was no implementation of the curriculum; most of the students were not supported to learn. Only 27 out of 60 students were supported to learn, yet the assistance was very limited so curriculum was not implemented. Findings revealed that when schools were opened various strategies were adopted by the schools to compensate the time that was lost during schools closure, these include, adjustments in the school timetable, improvement in assistance by teachers, encourage peers assistance and encourage learners to read by borrowing books. These strategies helped the schools to compensate the time lost also to cover up most of the subject contents. Few learners who were left behind by teachers due to high speed to teaching were assisted by their fellows. The researcher recommends that the Government should invest much on technology in educational institutions where teachers and student could meet online even when they are separated. The researcher also recommends further study to be conducted on the effects of the COVID 19 on the primary school curriculum implementation. Also the same study can be conducted in other Regions.
\end{abstract}

Key words: COVID 19, Effects of COVI 19, Curriculum, Curriculum implementation, the curriculum implementation during the school closure.

DOI: $10.7176 /$ RHSS/11-18-09

Publication date:September $30^{\text {th }} 2021$

\section{Introduction}

Corona virus pandemic (COVID-19) is now dominating the lives of everyone, and its history is constantly being rewritten. On $31^{\text {st }}$ December 2019, the World Health Organization (WHO) was formally notified about a cluster of cases of pneumonia in Wuhan City, home to 11 million people and the cultural and economic hub of central China. WHO was aware of 282 confirmed cases, of which four were in Japan, South Korea and Thailand (Tarimo $\& \mathrm{Wu}, 2020)$ The cause of the severe acute respiratory syndrome that became known as COVID-19, was a novel corona virus; SARS-CoV-2. On March 11, 2020 the World Health Organization (WHO) declared Covid-19 a global health emergency, no cases had yet been reported in Tanzania. Some people within the country initially thought the contagion could not spread to warm tropical areas like Tanzania (Steve, 2020) but this was different, the pandemic spread all over the Country. On $16^{\text {th }}$ March 2020, the Ministry of Health of Tanzania announced the first case of COVID-19. The victim happened to be a female traveller aged 46 years who visited Belgium, Denmark and Sweden between the dates $5^{\text {th }}$ and $13^{\text {th }}$ of March 2020. On the $15^{\text {th }}$ March 2020, the lady flew back to Tanzania where she was diagnosed with the virus a day latter to her arrival. The situation might also mean Tanzania may have a number of imported cases currently large, posing a huge threat to public health, (Steve, 2020). The effects of the pandemic have been experienced all over the World so far. The report by ESRF, (2020) shows that COVID 19 has affected all aspects of human life; these include economic sector, health and education 
just to mention a few. This paper presents and discusses findings of a study conducted from 2020 to 2021 on the effects of schools closure for three months between March 2020 and June 2020 as a result of the COVID 19 pandemic. The study, which focused on how learners were supported to learn before, during and after the school were opened was guided by Vygotsky's socio cultural theory of learning. The theory emphasises that learning is more effective when learners are supported by More Knowledgeable Others (MKO). It is understood that school learning follows the school curriculum and is mainly facilitated by teachers, who are the main implementers of the curriculum.

From the definition of the Curriculum, with the general meaning of all the planned activities that the student is expected to do during school time. It is the real adoption of the curriculum or curriculum materials such as syllabus, scheme of work, text and reference books by teachers, learners and other stakeholders using a selected approach, methods and a variety of techniques. Curriculum is also referred to as; all of the educative experiences learners have in an educational program, the purpose of which is to achieve broad goals and related specific objectives that have been developed with a framework of theory and research, past and present professional practices and changing needs of the society (Parkay, 2010).

So, for the curriculum to be implemented there has to be a well prepared environment particularly at school where teachers and learner meet under specific guidance of the syllabus which govern what the students learn and what the teacher should teach in the classroom. This means during the normal school break such as Easter break and End of the year break, there is no curriculum implementation as teachers and learners are separated. These are examples of the normal schools break which are recognized by the Government and they are always included in the school calendar. The schools do break to give time to both teachers and student to do self evaluation and check the progress of the teaching and learning process. Hence it is clear that in order for teaching and learning process to take place there has to be a planned program, teachers and learners in a well defined area under the specific guidance of the syllabus. So the researcher was interested to find out what happened to the curriculum implementation when the schools were forced to close for three unplanned months that resulted from the COVID 19 pandemic. The report by UNESCO (2020) explained that Education systems around the world are facing an unprecedented challenge in the wake of massive school closures mandate as part of public health effort to contain the spread of COVID 19. Over 1.5 billion students at all levels are now affected by this educational disruption.

The school closure as a result of COVID 19 directly not only affects the learning and teaching activities among both teachers and students but also the whole process of curriculum implementation. After the eruption of the pandemic the Government announced the closure of all education institution for unknown period of time so as to reduce the spread of the pandemic. One among the effects of the pandemic in education sector was the stop of curriculum implementation process at schools since there was no meeting between teachers and students also there was no teaching and learning process, as all schools were forced to close for almost three months. The three month school closure greatly affects the academic status of teachers and students, also other stakeholders who participate in provision of education and supervision of the curriculum implementation. Learners were separated from teachers and their fellow peers so learners were not assisted at school.

\section{Statement of the Problem}

COVID 19 pandemic has been a threat all over the world, and its impacts have been experienced in the education provision system all over the world so far. This study will look at how COVID 19 has affected the teaching and learning process in secondary schools in Morogoro Municipality.There is a need for such a study in order that, ways can be sought to compensate any losses or reduce the negative effects of the pandemic on teaching and learning process. Several studies have already been conducted on the effects of COVID 19 in different sectors such as tourism, health and economic development and education. For instance UNESCO, (2020) has conducted an online survey, looking at challenges of school closure and on mitigating the problem after re opening. The findings also show that, most of the Governments in the World struggle to minimize the effects of the pandemic. Most of their education systems were facing a number of challenges due to school closure, these challenge include; the impact on students health and well-being, social isolation, food, insufficient readiness of the parents and caretakers. The findings obtained from the survey provided worldwide overview responses to the effects COVID 19 related to school closure. These will help to inform on measures and strategies to ensure continuity of learning in different context. These studies have been conducted in other countries such as Sudan, Portugal and Rwanda.

There has been no much research in Tanzania since the outbreak of the pandemic, few conducted studies have based mostly on the effects on other sectors particularly health. There is a need to look further on the effects of 
COVID 19 in curriculum implementation since education is one of the affected sectors by the pandemic. It is clear that there is a need for further study to be done as it will open the door for other researchers who wish to explore more on the effects of COVID 19 in education (World Bank 2020). Also it will help to show the actual effects of the pandemic in curriculum implementation. It is important for the issue to be known as the whole society has been affected and so does the education provision systems too and the curriculum implementation process. So it is on this basis that the researcher wishes to look further on the effects of COVID 19 in implementing the secondary school curriculum basing on how the learners were supported /assisted to learn before the pandemic, during the pandemic and after the re-opening of the school, which will tell how the curriculum was implemented.

\section{Theoretical Underpinnings}

The study was guided by Social Constructivism Theory by Levy Vygotsky. His theory of Social constructivism (Socio-cultural theory) rests on the theoretical assumption that reality and knowledge are emergent and situated in the social context and constructed as people engage with others in joint activities. It focuses on dialogic meaning making resulting from interaction between the individual and their environment (Pritchard \& Woollard, 2013). This implies that knowledge is constructed through social interaction in teaching and learning process. Vygotsky emphasizes the importance of collaboration between the teacher, student and student with each other, as social interaction is viewed as a primary means of children to construct new meaning. Furthermore, he describes a Zone of Proximal Development (ZPD) which is a region of activity that learners can navigate, but with the assistance from teacher, other people and other sources (Gagnon \& Collay, 2006). He incorporated the distance between what a child can perform independently and what can be achieved in collaboration with someone more capable. In the ZPD, children and adults or more capable partners engage in cooperative dialogues in which teaching and learning merge in a single integral process of joint performance (Fosnot, 2005). From this ground it is clear that social interactions play a big role in supporting learner's learning ability, understanding and generally, the implementation of the curriculum. So when there is no interaction between teachers and students also between peers the teaching and learning process is disturbed. Vygotsky, (1978) insisted that, learning is a social activity; it is something people do together in interaction with each other, rather than an abstract concept. So it is clear that no learning was taking place when schools were closed and hence curriculum was not implemented since there was no interaction in schools. Therefore the researcher was interested to find out on how was the curriculum implementation before the pandemic, what happens to the implementation of the curriculum when the school were closed for three month as the result of the pandemic and lastly was the focus on strategies were adopted by the school to compensate the time lost after the schools were re-opened. This study will focus mainly on the effects of COVID 19 on implementing the Secondary School Curriculum in Morogoro Municipality, Tanzania. The interest of the researcher came as a result of researcher's 8 years experience as a secondary school teacher. As during the entire teaching the researcher noticed that during the holiday breaks most of the teachers and students do lose their concentration and interest in academic matters. For instance, it is very likely for most of the students to forget most of the contents that were taught before the holiday break, others will even complain of losing their text and exercise books during break time and some will not attend school for weeks or more with no reasonable issues. On teacher's side, the matter is even worse, as to some of them it could take a week or more to be back in the mood and ready to teach, others will teach without any preparation such as teacher's lesson plans and notes. This is just a few examples of the effects of school closure as a result of normal planned holiday break. Agreeing with Vygotsky's idea that "learning is a social activity which takes place when learners and teachers interact with each other, rather than an abstract concept" (Vygotsky, 1978). So when social interaction is cut-off, learning is affected as well as the level of understanding and generally the implementation of the curriculum. It is clear that learner's assistance is always interrupted when teachers and learners are apart, as it is manifested on researcher's own experience. From this perspective the researcher was hence interested to find out how the three months of unplanned schools closure which resulted from the pandemic affected the implementation of the secondary school curriculum.

\section{Methodology}

This study used qualitative approach. Deters (2011) argues that qualitative research strives for a deep understanding of the participants in a particular setting; the researcher must go to the participants and the sites in order to collect data in a natural setting. Therefore qualitative approach was used because it enables the researcher to be more focused and get in-depth information about issues of related the effects of COVID 19 in implementing the secondary school curriculum. The researcher entered deeply into the feelings, views, opinions, 
and ideas of informants through focus group discussion and interview to get holistic description of the phenomenon as qualitative research demand. The study adopted a case study design as the most appropriate guide for this work because, the case study allows the researcher to focus much on one entity which is Morogoro Municipality. This region was randomly selected to represent other regions in Tanzania which have teachers and schools with more or less the same characteristics. Cohen, (2007) postulates that, case study provides insights into other, similar situations and cases. The target population usually has varying characteristics and it is also known as the theoretical population (Blaxter \& Hughes, 2006). The target population in this study included teachers, Form three student and parents from school A, B1, B2, C1, and C2. From such population, the researcher selected a sample which provided information on the effects of the COVID 19 on curriculum implementation by focusing on implementation before the pandemic, assistance to learn during the pandemic and the compensatory strategies after schools re-opened. The sample is a small proportion of the population that is selected for observation and analysis (Kahn \& Best, 2006). In this study, the researcher's sample included five Ordinary level secondary schools in Morogoro Municipality, where he involved Teachers, Form three students and parents in the study to give information on the effects of COVID 19 pandemic in the implementation of the secondary school curriculum. They were all selected using purposive sampling technique. The samples were presented as follows

Table 1: Expected sample Size

\begin{tabular}{|l|l|l|l|l|l|}
\hline S/n & $\begin{array}{l}\text { Name of } \\
\text { Secondary school }\end{array}$ & Teachers & Parents & $\begin{array}{l}\text { Form three } \\
\text { students }\end{array}$ & $\begin{array}{l}\text { Total } \\
\text { respondents }\end{array}$ \\
\hline 1 & $\begin{array}{l}\text { School "A" } \\
\text { (high economy) }\end{array}$ & 4 & 2 & 12 & 18 \\
\hline 2 & $\begin{array}{l}\text { School "B1" } \\
\text { (Middle/Mixed } \\
\text { economy) }\end{array}$ & 4 & 2 & 12 & 18 \\
\hline 3 & $\begin{array}{l}\text { School "B2" } \\
\text { (Middle/Mixed } \\
\text { Economy) }\end{array}$ & 4 & 2 & 12 & 18 \\
\hline 5 & $\begin{array}{l}\text { School "C1" } \\
\text { (Low economy) }\end{array}$ & 4 & 2 & 12 & 18 \\
\hline $\begin{array}{l}\text { School "C2" } \\
\text { (low economy) }\end{array}$ & 4 & 2 & 12 & $\mathbf{9 0}$ \\
\hline
\end{tabular}

Sources: Field data, 2021

\subsection{Data Collection Procedures}

The data collection method is a process of gathering specific information aimed at providing or rejecting some facts (Kothari, 2004). The researcher will use a variety of methods for data collection; more than one method of data collection will be applied since the variety of methods increase the validity and reliability of data collected (Adams \& Hafiz, 2007). The current study uses both, the primary and secondary sources of data. The researcher gathered primary data through semi structured-interviews and focus group discussion and secondary data through reviewing of related literature. The secondary data focused more on the information from text books, journals, researches and other relevant related literatures on the effects of COVID 19 in the curriculum implementation. The researcher collected data basing on the main themes of his study. The first data collected shows the effects of COVID 19 on curriculum implementation in terms of learner's assistance to learning before the eruption, Secondly the data shows the effects of COVID 19 on learner's assistance when schools were closed, third data 
were about the strategies used by the schools to compensate the time lost after the re-opening of the schools. Such information helped and guided the researcher in the process of verifying and satisfying the research goals and questions set to make sound judgments of the research findings. The researcher used various techniques to collect information in this study to assess on the effects of COVID 19 in the secondary school curriculum implementation. The study used two instruments in the process of data collection, because the use of more than one specific techniques (triangulation) enables the researcher to cross-check and strengthen the data gathered, which makes the gathered data reliable (Creswell, 2010). The methods of data collection used were semistructured interviews to teachers and parents and Focus Group Discussions with students. The researcher preferred the use of FGDs because his study was a qualitative in nature, which did not involve extensive statistical analysis.

The reason for preferring each interview to teachers and parents were, first, to maintain confidentiality and give every individual interviewee freedom to talk and express his/her views and attitudes about the COVID 19 pandemic on curriculum implementation, and second reason was due to their small numbers which did not allow the use of Focus Group Discussion (FGD), as the respondents number for FGD is between 6 and 12 (Tayie, 2015). The researcher did not meet these requirements because in each school, he interviewed 4 teachers and two parents only. These were right according to the qualitative nature of the research conducted. The collected data were analysed descriptively. The analysis of the data was influenced by a number of data sets such as students, parents and teachers who participated in this study. Data obtained in this study were be analysed by descriptive approach that involves content analysis which is the process of summarizing and reporting written data and their messages.

\section{Findings and Discussion}

The researcher focused on the assessment on how learners were assisted to learn during the pandemic. This was particularly during the three month school closure. The researcher was interested to find out on what happened to the learner's assistance when the schools were closed as a result of COVID19. The researcher posed some questions through semi- structured interview to the parents and conducts a Focus group discussion with Form three students from the selected secondary schools. Findings show that learners were supported to learn at home and at tuition centres only. The analyses of the findings are in the next sub-section.

\subsection{Context for learning during the school closure}

The researcher was interested to find out on where the learner was assisted to learn during the school closure. Findings revealed that learners were assisted to learn at home and at tuition centres. Through semi-structured interviews with 10 parents the researcher gathered the information as shown in the Table bellow;

Table 2: Parents responses on context of assistance to learn during the pandemic

\begin{tabular}{|l|l|l|l|l|}
\hline \multicolumn{2}{|l|}{$\begin{array}{l}\text { Secondary schools \& Total } \\
\text { Number of respondents }\end{array}$} & Assistance at home & Assistance at tuition centres & Not assisted at all \\
\hline School (A) & 2 & 1 & 1 & 0 \\
\hline Schools (B1 \& B2) & 4 & 1 & 1 & 2 \\
\hline Schools (C1 \& C2) & 4 & 2 & 0 & 2 \\
\hline TOTAL 10 & 4 & 2 & 4 \\
\hline
\end{tabular}

Source: Researcher, 2021

From the data obtained it shows that 6 out of 10 learners were assisted to learn at home, and only 2 students were assisted at tuition centres, 4 students were not assisted to learn at all during the pandemic. The researcher first wanted to find out on kinds of assistance that was given to the learners at home during the school closure. The researcher turned this question to the students. Through focus group discussion with the form three students the 
researcher was able to get the following responses on the context of assistance during the pandemic (schools closure)

Table 3: Students responses on context of assistance to learn at home during the pandemic/school closure

\begin{tabular}{|l|l|l|l|l|}
\hline $\begin{array}{l}\text { Secondary schools \& } \begin{array}{c}\text { \& } \\
\text { Total } \\
\text { respondents }\end{array} \\
\text { School (A) }\end{array}$ & $\begin{array}{l}\text { Assistance at } \\
\text { home }\end{array}$ & $\begin{array}{l}\text { Assistance at tuition } \\
\text { centres }\end{array}$ & Not assisted at all \\
\hline Schools (B1 \& B2) & 24 & 9 & 2 & 5 \\
\hline Schools (C1 \& C2) & & & 2 & 13 \\
\hline & 24 & 8 & 1 & 15 \\
\hline TOTAL & $\mathbf{6 0}$ & $\mathbf{2 2}$ & $\mathbf{5}$ & $\mathbf{3 3}$ \\
\hline
\end{tabular}

Source: Field Data 2021

From the table above it was revealed that only 27 students out of 60 were assisted to learn at home during the schools closure. This means 33 students were completely not assisted to learn at all. The researcher was first interested to know the kinds of assistance that was give to the learners at home during this time.

Table 4: Students responses on the kinds of assistance to learn at home during the pandemic/school closure

\begin{tabular}{|l|l|l|l|l|l|l|}
\hline $\begin{array}{l}\text { Secondary } \\
\text { school \& } \\
\text { Number of } \\
\text { respondents }\end{array}$ & $\begin{array}{l}\text { Assistance } \\
\text { through } \\
\text { TV }\end{array}$ & $\begin{array}{l}\text { Assistanc } \\
\text { e through } \\
\text { other } \\
\text { online } \\
\text { sources }\end{array}$ & $\begin{array}{l}\text { Assistance } \\
\text { by parents } \\
\text { and relative }\end{array}$ & $\begin{array}{l}\text { Assistance } \\
\text { through } \\
\text { books }\end{array}$ & $\begin{array}{l}\text { Assistance } \\
\text { through past } \\
\text { papers }\end{array}$ & $\begin{array}{l}\text { Assistance at } \\
\text { Tuition } \\
\text { centres }\end{array}$ \\
\hline School (A) 7 & 2 & 1 & 1 & 1 & 1 & 1 \\
\hline $\begin{array}{l}\text { Schools (B1 } \\
\text { \& B2) 11 }\end{array}$ & 2 & 1 & 2 & 2 & 2 & 2 \\
\hline $\begin{array}{l}\text { Schools (C1 } \\
\text { \& C2) } 9\end{array}$ & 1 & 0 & 3 & 3 & 1 & 1 \\
\hline TOTAL 27 & $\mathbf{5}$ & $\mathbf{2}$ & $\mathbf{6}$ & $\mathbf{6}$ & 4 & 4 \\
\hline
\end{tabular}

Source: Field Data 2021

From the table above it is clear that learners were assisted to learn at home when schools were closed. Below is the description of each kind of assistance that was given to the learner at home during the pandemic.

\subsubsection{Assistance through TV}

Findings show that during the pandemic learners were assisted watching some live and recorded show through TV. This is vividly as the findings show 5 students were assisted to learn through TV. One student from school B1 said:

"During the school closure I was watching live classroom at AZAM channel. I was able to learn a lot of staff that are related to my subject"

Another student from school A comments that: 
"I was watching live classes at CLOUDS TV every Saturday. This helped me to improve a lot in my studies"

\subsubsection{Assistance through other online sources}

Findings revealed that 2 students out of 27 were assisted to learn by online programmes. This was well elaborated as one student from school B2 said:

"During the school closure I was searching some note through online application such as Google and SHULE DIRECT"

Another student from school B2 said:

"My father allowed me to use his laptop to search for some notes and some elaboration which were found online. I used Wikipedia website to search for many subjects contents"

Another student from school $\mathrm{C} 1$ comments further that:

"Whenever I had some difficult terms I asked my mother for help, where she used her phone to search for some answers and more elaboration from online source"

\subsubsection{Assistance by parents and relatives}

Findings also show that 6 students out of 27 were assisted to learn by their parents and relatives. This was proved as one student from school A said:

"When the schools were closed, I found my brother from University, who assisted me in my studies"

Another student from school C1 said:

"My Uncle who is a teacher was assisting me in most of the science subjects; he really helped me to improve in my studies"

One more comment was given by another student from school $\mathrm{C} 2$ that:

"My mother was assisting me most of the time, when I got some difficult in my studies"

Another student from school B1 comment:

"During the school closure time I was discussing with my relative whom we met at home during the pandemic.

The discussion helped me to improve in English subject",

One more student from school B2 said:

"I had enough time to make discussion with my brother. He assisted me whenever I had problems; he was really helpful to me during the whole school closure time"

\subsubsection{Assistance through books}

Findings show that there are 6 students out of 27 who were assisted to learn through books. One student from school B2 comments that:

"I am glad I took some books with me when we close the school. They were very helpful as I had enough time to do some revision and make practice on many exercise from the books"

Another student from school C1 said:

"I had some review books on different subjects, so I used the school closure time to solve a lot of questions and I checked for the answers which were at the last page. This helps me to be competent in many subjects"

\subsubsection{Assistance through past papers}

Findings also revealed that 4 student were assisted to learn through past papers. This was through solving past examination as one student from school A said:

"When the schools were closed I had some past National examination, so I used the time effectively to solve many questions from previous exams. They made my mind sharp and ready for the upcoming examinations"

Another student from school B2 also said:

"Through past papers I was able to solve a lot of questions which I was not able to do so before the schools were closed"

\subsubsection{Assistance through tuition centres}

Findings revealed that 4 students out of 27 were assisted to learn through tuition centres. These were those whose parent paid for private teachers to assist their children, particularly at home. One student form school B1 explained that:

"My parent paid for a private teacher who was assisting me in my studies at home. This helped me not to lose concentration with school contents"

Another student from school A said: 
"When the schools were closed I was not able to go visit my friend whom we discussed together, so my Father looks for me a private teacher who was assisting me at home alone"

The researcher wanted to find out why 33 of the learners were not assisted to learn during the school closure. Through Focus group discussion the researcher was able to identify some of the challenge.

\subsection{Challenges of assisting learners at home during school closure}

Findings revealed that there are numbers of challenges that forced some of the students not to be assisted to learn at during the school closure. The responses from the students on the challenges are shown in the table bellow;

Table 5: Responses on the challenges of assistance at home during school closure.

\begin{tabular}{|l|l|l|l|}
\hline $\begin{array}{l}\text { Challenges of home assistance during } \\
\text { schools closure. }\end{array}$ & \multicolumn{3}{|l|}{ Secondary schools \& Number of respondents } \\
\hline & School A & Schools B1 \& B2 & Schools C1 \& C2 \\
\hline No teachers to assist & 1 & 1 & 1 \\
\hline No peers for discussion & 1 & 1 & 2 \\
\hline $\begin{array}{l}\text { Lack of parents and teachers } \\
\text { readiness }\end{array}$ & 1 & 2 & 2 \\
\hline Lack of schools readiness & 1 & 1 & 1 \\
\hline Lack of materials & 0 & 2 & 2 \\
\hline $\begin{array}{l}\text { Uneven distribution of network \& } \\
\text { electronic facilities }\end{array}$ & 0 & 2 & 2 \\
\hline Lack of power & 0 & 2 & 3 \\
\hline Unsupportive home environment & 1 & 2 & 2 \\
\hline TOTAL RESPONDENTS 33 & $\mathbf{5}$ & $\mathbf{1 3}$ & $\mathbf{1 5}$ \\
\hline
\end{tabular}

Source: Field Data 2021

The table above shows the number of challenges that hinder the process of learner's assistance at home during the pandemic. These include the following:

\subsubsection{No teachers to assist the students at home}

Findings show that students were not assisted to learn during the pandemic because teachers were not there. This was a comment of one parent from school B1 who said:

"Students were not assisted to learn because there were no teachers or peer students to assist them when schools were closed. This was due to the fact that no meeting was allowed during the three month closure time"

\subsubsection{No peers for discussion}

Findings also revealed that some learners were not assisted during the pandemic because they had no peers for discussion. one parent from school A comments that: "Private study was very difficult to some of their children as they used to study in groups with their fellows and also they were assisted by their teachers in schools, so cut- off the meeting of the teacher and the student means no learning was taking place"

This was also evident as another parent from school $\mathrm{C} 1$ said:

"...He tried to study alone for some weeks after the school was closed, but he found it to be difficult, he was so bored to study alone at home..."

Another parent form school B2 also comments that: 
“... you know when he study alone there is no one to challenge him he is not studying for long. The motivation to carry on is very low..."

Another parent from school B1 went far and said:

“... My child could not ask any one question for things that were not clear to her. Studying alone was very hard"

\subsubsection{Lack of parents and relatives readiness}

Findings have identified that most of the parents were not prepared to stay with their children at home for three month, so it was difficult for some of the parents to assist their children to learn at home. It was also revealed that most of the parents were not well equipped with enough skills and devices such as computers and smart phones to assist their children as they could not use properly the devices.

As one parent from school C1 said: "Some of us are not skilled enough to search for material through their telephone to assist the learner"

Findings also revealed that, some parents were not having the smart phone at all so the assistance to learn through online materials. This was a big challenge to most of them.

One parent from school B2 said:

"They are talking about smart phone; I don't even know how to use it."

Another parent said:

"I don't have even a Television at home, so that my child could watch some live classroom, and learn"

\subsubsection{Lack of schools readiness}

It was further revealed that most of Government schools were not prepared for this, no any program that was prepared to connect teachers and students when schools were closed. One Parent said that:

"Most of the students relay on the notes they were given before the schools were closed and for the few who had books to study on because there was no any program developed to connect teachers and student when school were closed"

Findings also show that the unexpected long holyday result into most of the learners not to be assisted during the pandemic.

One parent said that:

"Most of the students and teachers did not expect that, the school closure would take three month, so they were sitting and wait for school to be opened"

\subsubsection{Lack of materials for assisting learners}

Findings show that most of the learners were not assisted to learn during the pandemic because there were no supporting documents to assist the leaner such as books. As one student from school B1 said:

"Most of the learners were much affected by the three month closure which was as a result of the pandemic, they forget most of the content because they were not studying hard at home and they were not assisted. This was due to the fact that we had no materials such as books, journals and notes to assist us in our learning"

One student from school $\mathrm{C}$ comments further that they lack motivation to learn:

"Most of us were relaxing at home...I did not study hard at home because there was no any examination ahead"

(Student from school B2)

Findings revealed further that some parents travelled with their children and they did not carry anything for studying. This was evidently as one parent from school B1 said:

"I travelled with all my family to the village area where there is less contact with people"

Findings also show that some learner's home environment was not conducive for assisting learners. One student comments that: 
"We don't have TV at our home so I could not watch any live classroom on TV. My parents are too old they don't have smart phone, I cannot access any online material through telephone"

\subsubsection{Uneven distribution of network access and electronic facilities}

Findings also show that there are some learners who were assisted at home during the school closure, these were assisted through some TV channels and live online programs which were accessed through their parent's telephone, computers and for those who had TV at their home.

But this kind of assistance was limited. Findings show that most of the learners were actually not assisted well at home learn due to the absence of reliable network and electronic facilities such as computer. Two of the respondent said that.

"Most of the parents were not having those devices. Some parents could not afford to buy data for the device, so that learners could be assisted to learn"

(Student from school B2)

Parents from school B2 said:

"In most rural areas and some remote areas in Town do not have reliable internet connection, it is due to this uneven distribution and high cost of accessing internet that hinder the assistance of most of the learner"

Finding also revealed that cost was another challenge that makes some learner not to be assisted. One student said:

"My father has a computer where I could access some materials and use them for my studies, but he could not afford to have internet access all the time because it was too expensive"

\subsubsection{Lack of power}

Findings also show that power availability was also a challenge in assisting learner to learn.

"Since most of the device to assist learners such as computer and TV uses electricity, so absence of it means no assistance"

Some parents said that not all houses have power that is electricity, due to high cost of the service. This was vividly expressed by one parent who said:

"I don't have electricity in my house. I cannot afford the cost of installing the service, it is too expensive"

\subsubsection{Unsupportive home environment}

Findings revealed that some learner were busy occupied with home activities which were left by their parents, this include selling the shop and others attend in farm activities, there was no assistance that was given to such learners. . As one student said:

"... My father said to me that, he is glad that I am home, so that I can take care of the house activities"

One student from school B1 said:

"... My father told me that I will stay at the shop and he will go to do some other thing"

Some travelled to their relative and they did not take any exercise book with them so they spent the whole time with other no academic staffs and they were not assisted at all.

One student from school B1 said:

"I travelled with my parents to the village, and I did not take with me any material for studying"

From the findings the researcher gathered it is clear that learner's assistance to learn during the eruption was cut-off. This was due to the schools closure. Most of the students were not assisted to learn at that time, few were assisted to learn at home and at tuition canters even though this kind assistance was very limited in terms of personnel and the content that was given to the learners. Findings revealed that the assistance at home was only for the first month, most of the learners and those who assisted them were tired due to the un-planned long break. So the curriculum was not implemented during the pandemic. 


\section{Discussion and Conclusion}

Findings indicated that the curriculum implementation from the selected sample secondary schools was affected when the pandemic strikes. Several effects of the COVID 19 were experienced including the school closure for three months. Teachers and students were not allowed to meet, due to the new condition that were put by the Government. Findings show that this separation result into a bigger problem in the learning process as most of the students depend on the assistance at school, very few were assisted at home and at tuition centres. As a result most of the learners were not assisted at all when the schools were closed. From Vygotsky's point of view who insisted, on the role of social interaction in supporting learner to learn so as to improve the understanding capacity, it is clear that when there is no interaction between students also between teachers and students no learning is taking place, the assistance the learner get from his fellow will help him develop better in his ZDP but it would be difficult to develop or attain on their own. One among the major effect of the pandemic was the schools closure and this was not planned. Most Countries in the World were forced to close all their education provision institutions as one of the ways to reduce the spread of the pandemic. In most countries the schools were closed for three months and some were closed for 6 and more months. The study conducted by UN, (2020) has described some of the effects of the pandemic on education systems which include huge number of learners to be forced out of school.

This action resulted into the disruption of the education provision system where teachers and students were separated as a result the implementation of the curriculum which is usually planned to be implemented in a specific period of time under the supervision of teachers was also affected. From the social constructivist theory that emphasizes on support in learning by more knowledgeable ones, it means that, during the closure of the schools learners lack someone who could assist them to learn at home. Findings revealed that there are numbers of the effects that resulted from school closure which were as a result of the pandemic and these affect the teaching and learning process, these include: Wastage of time which was mentioned by both teachers and students that the pandemic resulted into loss of time particularly during the closure where there was no any schooling takes place. So the curriculum implementation was affected since the unplanned break disturb most of the time table, as the break came as a surprise most of the teachers and students were not prepared for it, and the close of the school was not expected to be of that much long. Most of them were tired and some even lose hope if the schools were going be opened soon. The three month closure was a total loss to most of the students as most of them were just relaxing at home they were not studying at all.

Poor planned school timetable which resulted from the pandemic affected the curriculum implementation among both teachers and students. Findings revealed that the new time table forced teachers to teach a lot of content at a short time as a result most of the students were left behind not understanding most of the taught contents. The new timetable was not friendly to the teachers as they had very little time to check on learners understanding and progress. The new time table also results in increasing truants among students, which was caused by the extension of two more hours where most of the students were not attending the afternoon session due to tiredness. Teachers were also tired because the number of period increased and the school demanded them to provide many assignments to the students to keep them busy. Some of the students were just sleeping due to hunger and tiredness. The new timetable left students with very little time for group discussion and even time for consulting teachers was very little. Indeed it was not a friendly kind of timetable to most of the students.

Findings also show that the pandemic results into many teachers not to complete the syllabus. It revealed that most of the teachers were not able to complete all topics as the syllabus indicates because the time was very limited. This was due to the nature of some subjects which had a lot of topics which are very long, so it was a total loss, to them when the schools were closed for three month, they couldn't finish all the topics at the end of the year. The pandemic result into most of the student forgets what they learned before the schools closure as a result most of them did bad in their examinations. Findings show that there was a huge change in learner's assistance during the eruption of the pandemic. The assistance to the learners at school was cut- off completely due to the schools closure. Learners depend on the assistance to learn at home and tuition centres only. It was discovered that 8 out of 10 parents who were interviewed said that their children were not assisted to learn at home when the schools were closed for three months. The respondents gave the reasons to why learners were not assisted to learn when the schools were closed, these include the following: One of the reasons was that, when school were forced to close teachers and students could not meet. Therefore assistance at school was not there and learners were forced to find other means of assistance at home.

Few who were assisted at home, got help from their parents, particularly those who were teachers, and those who were aware some subjects, learners were also assisted by their relatives whom they met at home, and most these were from universities and higher classes. They assisted the learner although the assistance was limited. Some 
were assisted to learn through TV, where they could watch some live lessons from different channels, also through some online websites which could be accessed through computers or smart telephones. Through these sources learners could access notes, live classes and demonstrations. This is similar to what was found in the report by UNESCO (2020) where, China has launched a nationwide campaign to accelerate the integration of ICT in education during the pandemic, including facilitating the online learning activities, establishing national platform to accommodate millions of students learning online.

The researcher found that there are number of challenges that resulted into some of the learner not to be assisted to learn during the pandemic, these include the following: Poor home environment, no teachers for assistance, no peers for discussion and power problems, just a few to mention, were among many challenges that resulted into some of the learners to be assisted while others were not assisted to learn. The other reason seems to be the unpreparedness of the parents and caretakers to facilitate learning at home. Most of them might not be read to care for the children due to other duties and commitments, which is similar case to that of the report by UNESCO, (2020) where in Sudan, For instance respondents said that illiterate parents would not be able to support their children's learning. The study conducted by ESFR, (2020) focuses more on the socio- economic effects of COVID 19, where education was also included. The report identified some the effects such as unequal access of internet facilities, increase in drop out and the misuse of school facilities. This means most of the students were not assisted to learn since they lack someone who was more knowledgeable to support them to learn. So it is clear that the implementation of the curriculum was directly affected by the pandemic since most of the students were not assisted at home. From the findings the researcher analyzed it was discovered that during the school closure the curriculum was not implemented, since the assistance to the learner was not effectively as very few learners were assisted to learn at home because there was less social interaction during that particular time and there was no schooling. Learner's assistance relies on other means of assistance particularly at home and few at tuition centres. But these kinds of assistances to learn were limited as not all learners were able to access them. Most of the learners depend on the assistance from home and from tuition centres, both of which were very limited, as a result most of the students were not assisted to learn completely, the curriculum implementation process was affected due to the fact that all students were forced to stay home and most of them had no one to assist to learn at home and those who were assisted, the assistance was limited. Most of the students spent their time doing other non-academic staffs which was similar case to teachers too. Very few were engaging in academic matters. Based on the findings of the study the following conclusion is drawn: It is true that the pandemic did affect the teaching and learning process in one way or another since the schools were closed for three months and there was no any schooling that was taking place at that particular time, so the curriculum was not implemented. The strategies that were taken by the school to compensate the time lost during the school closure were effectively but not to all learners as some were left behind due to poorly planned strategies which were adopted by the schools to compensate the time lost, but they were assisted by their fellows at school.

\section{Conclusion and Recommendations}

The researcher finally concludes that, from the findings of the study it was revealed that the COVID 19 pandemic affects the implementation of the secondary school curriculum, because it resulted in school closure, which in turn affects the interaction between teachers and students also the level assistance to the learner. So this indicates that the curriculum was not fully implemented and hence it is true that the pandemic affect the secondary school curriculum implementation process. Since this study was done in Morogoro Municipality only, the researcher recommends similar studies should be conducted in other Regions and districts, so as to examine the effects of the pandemic on curriculum implementation since the pandemic has affected every place in our country, this will help to determine the effects in other areas outside so that strategies to solve reduce the effects can be sought out.

The researcher also recommends similar studies should be conducted at primary school curriculum since this study focused only on the effects of the pandemic to the secondary school curriculum only.

\section{References}

Adams, J., Khan, J.V., Hafiz, T.A (2007) Research Methods for Graduate business and Social Science Students, New Delhi: Sage Publication.

Creswell, J.W. (2009) Educational Research:Planning, Conducting and Evaluating Quantitative and Qualitative Research, $2^{\text {nd }}$ Ed, USA: Pearson Education Inc. 
Cohen, L., Manion, L., \& Morrison, K. (2007) Research Methods in Education, $6^{\text {th }}$ Ed. New York: Rutledge.

Deters, P. (2011) Identity, Agency and the Acquisition of Professional Language and Culture, London: New York: Continuum.

Economic and Social Research Foundation (ESRF) (2020), Rapid socio Economic impact Assessment of COVID 19 in Tanzania. UNDP- Tanzania.

Fosnot, C. T. (2005) Constructivism: theory, perspectives, and practice, $2^{\text {nd }}$ Ed, New York: Teachers College Press.

Gagnon, G. W., \& Collay, M. (2006a). Constructivist learning design: key questions for teaching to standards. Thousand Oaks, Cliff: Corwin Press.

Kahn, V. J \& Best, W. J (2006) Research in Education, $10^{\text {th }}$ Ed. USA: Pearson Education Inc

Kothari, C.R (2004) Research Methodology: Methods and techniques, $2^{\text {nd }}$ Ed. India: New Age Publisher

Parkay, W. F. (2010) Curriculum Leadership: Reading for developing quality educational program. USA. PEARSON Education Inc.

Pritchard, A., \& Woollard, J. (2013) Psychology for the classroom: constructivism and social learning. London_; New York: Routledge.

Tayie, S. (2005) Research Methods and Writing Research Proposal, Cairo: Centre for Advancement of Postgraduate Studies and Research in Engineering

Steve, C. (2020) COVID19: A brief history and treatments in development https://onlinelibrary.wiley.com/doi/10.1002/psb.1843. Accessed on Jan 16, 2021

Tarimo, C.S., Wu, J. (2020) The first confirmed case of COVID-19 in Tanzania: recommendations based on lesson learned from China https://doi.org/10.1186/s41182-020-00214-x. Accessed on Jan 16, 2021

UNESCO, (2020) Corona virus Impacts Education https://en.unesco.org/themes/education-emergencies/corona virus-school-closures . Accessed on Jan 16, 2021

UN (2020) Policy brief Education during COVID 19 and beyond: The impact of COVID 19 on children https://unsdg.un.org/sites/default/files/2020. Accessed on Jan 16, 2021

Vygotsky, L.S. (1978) Mind in society: The development of higher psychological process. Cambridge, MA: Harvard University Press. 